\title{
A Performance Extension Measurement Analysis Model of Enterprise Green Technology Innovation based on Extension Theory
}

\author{
Yanrong Wang and Annan Chen \\ Management \& Economics School of North China University of Water Resources \\ and Electric Power, Zhengzhou, 450046, China \\ can5151@126.com
}

\begin{abstract}
Green technology innovation is the critical path for enterprises to achieve sustainable development. However, corporate green technology innovation in most cases is affected and constrained by multiple factors. It is featured by multi-factor, multi-target, multilayer and fuzzy uncertainty, etc. Thus it is of great importance to measure and analyze the performance of corporate green technology innovation. To this end, this paper aims to study the performance measurement of corporate green technology innovation and proposes a performance analysis model based on extension theories for corporate green technology innovation. First, the model analyzed relevant factors that influence performance measurement analysis of corporate green technology innovation. Then, based on the analysis, it established the performance measurement analysis index system of corporate green technology innovation. Meanwhile, the model tried to normalize the different types of measurement analysis indexes after which corresponding classical fields and controlled fields were obtained. It then calculated the extension distances and the extension dependencies between different measurement analysis indexes as well as the classical fields and the controlled fields. The size of the extension dependency revealed the ability levels of corporate green technology innovation. Lastly, the model was tested by specific cases.
\end{abstract}

Keywords: green technology innovation, performance analysis, extension theory, index system, measure model

\section{Introduction}

Along with the rapid development of science and technology, energy scarcity and environmental degradation are getting severer. When pursuing economic profits, corporates should consider more about the coordinative development of economy, society and environment. Therefore, green technology innovation, as a critical path for companies to achieve sustainable development, is attracting more and more attention and has been widely studied [1-3]. The purpose of green technology innovation is to help corporates maximize economic profits and social benefits and keep favorable sustainable development capacity under the following conditions: 1) save as much energy as possible; 2) save as much raw materials as possible; and 3) reduce environmental pollution. The essence of performance measurement analysis of corporate green technology innovation is to help science and technology enterprises maintain a favorable and healthy development [4-5]. The analysis of corporate green technology innovation capacity mainly evaluates their economic information, environmental benefit and social benefit, etc. So far, some scholars have conducted researches about the performance measurement analysis of green technology innovation and acquired some valuable insights [6-9]. Nevertheless, the existing methodologies often ignore the fuzzy uncertain measure 
information obtained during the performance measurement analysis process of green technology innovation. Although some methodologies adopt fuzzy analytical method to analyze the performance measurement of green technology innovation, they choose to generate accurate magnitudes of specific measure indexes before the measurement analysis. Strictly speaking, this is not genuinely fuzzy measurement analysis and cannot reflect the relationship between fuzzy indexes effectively. As a result, these methodologies have certain limitations. On the basis of existing research results, this thesis proposes an improved performance extension measurement analysis model of corporate green technology innovation from the perspective of extension theory.

\section{The Performance Measurement Analysis Index System of Corporate Green Technology Innovation}

The performance of corporate green technology innovation is influenced by various factors. It has features of multi-factor, multi-target, multi-layer, fuzzy uncertainty and dynamic, etc. Currently there is still no unified design philosophy of selecting measurement analysis indexes in the research field of performance measurement analysis index system design of corporate green technology innovation. Different scholars have different understandings about it. The author of this thesis thinks that the selection of indexes should ensure objectivity, accuracy and effectiveness of performance analysis results and it should also be able to conduct comprehensive performance measurement analysis from multiple perspectives and dimensions. This thesis presents a brand new performance measurement analysis index system of corporate green technology innovation as is demonstrated in Table 1. It is expected that this system can evaluate performance of corporate green technology innovation effectively, objectively, comprehensively and scientifically.

Table 1. Performance Measurement Analysis Index System of Corporate Green Technology Innovation

\begin{tabular}{|c|c|c|}
\hline System layer & Criterion layer & index layer \\
\hline \multirow{11}{*}{$\begin{array}{c}\text { Performance } \\
\text { measurement } \\
\text { analysis } \\
\text { index system } \\
\text { of corporate } \\
\text { green } \\
\text { technology } \\
\text { innovation } A\end{array}$} & \multirow{4}{*}{$\begin{array}{l}\text { green innovation research and } \\
\text { development capacity } A_{1}\end{array}$} & number of patents owned $a_{11}$ \\
\hline & & innovation development cycle $a_{12}$ \\
\hline & & $\begin{array}{l}\text { Independent research and } \\
\text { development rate } a_{13}\end{array}$ \\
\hline & & Training and learning ability $a_{14}$ \\
\hline & \multirow{3}{*}{$\begin{array}{l}\text { green innovation implementation } \\
\text { capacity } A_{2}\end{array}$} & level of green equipment $a_{21}$ \\
\hline & & level of green technology $a_{22}$ \\
\hline & & $\begin{array}{l}\text { proportion of professional green } \\
\text { technology personnel } a_{23}\end{array}$ \\
\hline & \multirow{4}{*}{$\begin{array}{l}\text { green innovation management } \\
\text { capacity } A_{3}\end{array}$} & $\begin{array}{l}\text { Entrepreneur's green innovation } \\
\text { consciousness } a_{31}\end{array}$ \\
\hline & & $\begin{array}{l}\text { Rationality of innovation } \\
\text { mechanism } a_{32}\end{array}$ \\
\hline & & $\begin{array}{l}\text { Rationality of innovation } \\
\text { mechanism } a_{33}\end{array}$ \\
\hline & & $\begin{array}{l}\text { Rationality of organizational } \\
\text { structure } a_{34}\end{array}$ \\
\hline
\end{tabular}




\begin{tabular}{|c|c|}
\hline \multirow{3}{*}{$\begin{array}{l}\text { green innovation marketing } \\
\text { capacity } A_{4}\end{array}$} & market share $a_{41}$ \\
\hline & $\begin{array}{l}\text { capacity of maintaining market } \\
\text { share } a_{42}\end{array}$ \\
\hline & Return on marketing $a_{43}$ \\
\hline \multirow{3}{*}{ green innovation input capacity $A_{5}$} & input-output ratio $a_{51}$ \\
\hline & $\begin{array}{l}\text { Conversion rate of scientific and } \\
\text { technical achivements } a_{52}\end{array}$ \\
\hline & invested cost $a_{53}$ \\
\hline \multirow{3}{*}{$\begin{array}{l}\text { green innovation development } \\
\text { potential } A_{6}\end{array}$} & $\begin{array}{l}\text { Intensity of green innovation } \\
\text { input } a_{61} \\
\end{array}$ \\
\hline & $\begin{array}{l}\text { High-tech projects of green } \\
\text { cooperation } a_{62}\end{array}$ \\
\hline & $\begin{array}{l}\text { Conversion cycle of green } \\
\text { technology } a_{63}\end{array}$ \\
\hline
\end{tabular}

\section{Performance Extension Measurement Analysis Model of Corporate Green Technology Innovation}

\subsection{Classical Field Matter Elements of Measurement Analysis Indexes}

Performance of corporate green technology innovation needs to be analyzed based on practical situation of corporate development. Hypothetically, there are $\mathrm{m}$ measurement analysis indexes that are obtained based on relevant research analysis and expert opinions in this field. And every index has n performance measurement analysis scales of corporate green technology innovation. Then the ${ }^{j}$ th scale classical field matter element model of measurement analysis index is ${ }^{\boldsymbol{R}_{j}}$ :

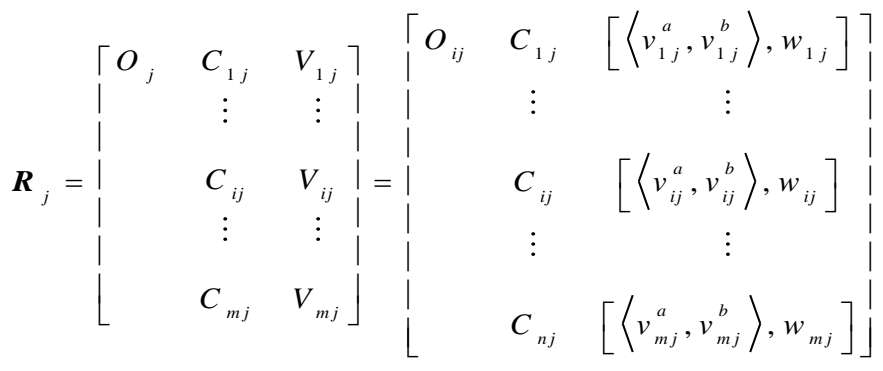

In the formula above, $V_{i j}=\left[\left\langle v_{i j}^{a}, v_{i j}^{b}\right\rangle, w_{i j}\right]$ refers to the characteristic value interval of the jth measurement analysis scale regarding to the ith measurement analysis index, which is the performance measurement analysis scale classical field of corporate green technology innovation of this index. And it satisfies $v_{i j}^{a} \leq v_{i j}^{b}, 1 \leq i \leq m, 1 \leq j \leq n$.

\subsection{Controlled Field Matter Elements of Measurement Analysis Indexes}

On the basis of constructing classical field matter elements of different measurement analysis indexes, controlled field matter elements of different measurement analysis indexes can also be constructed. 
If there is:

$$
V_{o j}=\left[\left\langle v_{o j}^{a}, v_{o j}^{b}\right\rangle, w_{o j}\right]=\left\lceil\left\langle\min _{1 \leq j \leq n}\left(v_{i j}^{a}\right), \max _{1 \leq j \leq n}\left(v_{i j}^{b}\right)\right\rangle, w_{i j}\right\rceil
$$

Then controlled field matter element model of measurement analysis index $\boldsymbol{R}_{o i}$ is:

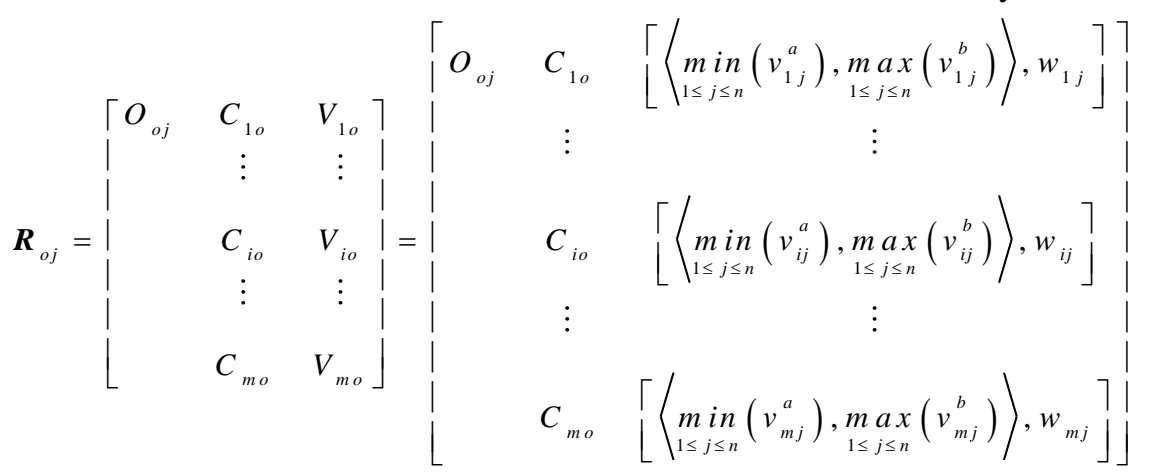

\subsection{Processing Performance Measurement Analysis Indexes of Green Technology Innovation}

It can be seen from the performance measurement analysis index system of corporate green technology innovation that among the indexes, some are quantitative which can be described precisely and some are qualitative which contain fuzzy information. The latter ones cannot be described by exact numbers and have fuzzy uncertainties. Their values can only be described by means of fuzzy memberships or fuzzy intervals. Meanwhile, some indexes are of benefit type and some are of cost type. In order to unify all the indexes, it is necessary to standardize them. To get a generalized description of the indexes, the paper assumes that all the indexes are fuzzy interval magnitudes while exact point values are exceptions of fuzzy interval magnitudes.

If the performance measurement analysis index $i$ is a reverse index, and its corresponding magnitude is $V_{i j}=\left\langle v_{i j}^{a}, v_{i j}^{b}\right\rangle$, then the corresponding magnitude of the transformed positive index of ${ }^{i}$ is ${ }^{U}{ }^{i j}$ :

$$
U_{i j}=\left\langle u_{i j}^{a}, u_{i j}^{b}\right\rangle=\left\langle\min _{1 \leq j \leq n}\left(v_{i j}^{a}\right) / v_{i j}^{a}, \min _{1 \leq j \leq n}\left(v_{i j}^{a}\right) / v_{i j}^{b}\right\rangle
$$

And if ${ }^{i}$ is positive index, and its corresponding magnitude is $V_{i j}=\left\langle v_{i j}^{a}, v_{i j}^{b}\right\rangle$, then its corresponding magnitude of the transformed reverse index is ${ }^{U_{i j}}$ :

$$
U_{i j}=\left\langle u_{i j}^{a}, u_{i j}^{b}\right\rangle=\left\langle v_{i j}^{a} / \max _{1 \leq j \leq n}\left(v_{i j}^{b}\right), v_{i j}^{b} / \max _{1 \leq j \leq n}\left(v_{i j}^{b}\right)\right\rangle
$$

If $i$ is, and its corresponding magnitude is $V_{i j}=\left\langle v_{i j}^{a}, v_{i j}^{b}\right\rangle$, then its corresponding magnitude of the transformed positive index is ${ }^{U}{ }{ }$ :

$$
U_{i j}=\left\langle u_{i j}^{a}, u_{i j}^{b}\right\rangle=\left\langle\min _{1 \leq j \leq n}\left(v_{i j}^{a}, v_{i j}^{o}\right) / \max _{1 \leq j \leq n}\left(v_{i j}^{b}, v_{i j}^{o}\right), \min _{1 \leq j \leq n}\left(v_{i j}^{b}, v_{i j}^{o}\right) / \max _{1 \leq j \leq n}\left(v_{i j}^{b}, v_{i j}^{o}\right)\right\rangle
$$




\subsection{Extension Dependency of Performance Measurement Analysis of Green Technology Innovation}

If the current magnitude of corporate green technology innovation regarding to the measurement analysis index $\mathrm{i}$ is the point value $V_{i p}$, then the extension distance between the magnitude and the jth measurement analysis scale is $\rho_{i j}^{p}$ :

$$
\rho_{i j}^{p}=\left|V_{i p}-\frac{u_{i j}^{a}+u_{i j}^{b}}{2}\right|-\frac{u_{i j}^{b}-u_{i j}^{a}}{2}
$$

If $V_{i p}$ is the middle point of the interval $\left\langle u_{i j}^{a}, u_{i j}^{b}\right\rangle$, then $V_{i p}$ is the closest from the jth measurement analysis scale, which means that $\rho_{i j}^{p}$ is the smallest.

If the current magnitude of corporate green technology innovation regarding to the measurement analysis index $\mathrm{i}$ is the interval magnitude $V_{i p}=\left\langle v_{i p}^{a}, v_{i p}^{b}\right\rangle$, then the extension distance between the interval magnitude and the jth measurement analysis scale is $\rho_{i j}^{p}$ as:

$$
\rho_{i j}^{p}=\frac{1}{2}\left(\left|v_{i p}^{a}-\frac{u_{i j}^{a}+u_{i j}^{b}}{2}\right|+\left|v_{i p}^{b}-\frac{u_{i j}^{a}+u_{i j}^{b}}{2}\right|\right)-u_{i j}^{b}+u_{i j}^{a}
$$

Particularly, when the optimal point of $V_{i p}$ is not at the middle point of the interval $\left\langle u_{i j}^{a}, u_{i j}^{b}\right\rangle$, if it satisfies $v_{i j}^{o} \in\left\langle u_{i j}^{a}, \frac{u_{i j}^{a}+u_{i j}^{b}}{2}\right\rangle$, then the current extension distance between the measurement analysis index i of corporate green technology innovation and the jth measurement analysis scale $\rho_{i j}^{p}$ is:

$$
\rho_{i j}^{p}= \begin{cases}\frac{\left(u_{i j}^{b}-v_{i j}^{o}\right) *\left(v_{i p}^{a}-u_{i j}^{a}\right)}{u_{i j}^{a}-v_{i j}^{o}} & \frac{v_{i p}^{a}+v_{i p}^{b}}{2} \leq u_{i j}^{a} \\ & \frac{v_{i p}^{a}+v_{i p}^{b}}{2} \in\left\langle u_{i j}^{a}, v_{i j}^{o}\right\rangle \\ v_{i p}^{b}-u_{i j}^{b} & \frac{v_{i p}^{a}+v_{i p}^{b}}{2} \geq v_{i j}^{o}\end{cases}
$$

If the condition of $v_{i j}^{o} \in\left\langle\frac{u_{i j}^{a}+u_{i j}^{b}}{2}, u_{i j}^{b}\right\rangle$ is satisfied, then current extension distance between the measurement analysis index i of corporate green technology innovation and the jth measurement analysis scale $\rho_{i j}^{p}$ is:

$$
\rho_{i j}^{p}= \begin{cases}\frac{\left(u_{i j}^{a}-v_{i j}^{o}\right) *\left(u_{i j}^{b}-v_{i p}^{b}\right)}{u_{i j}^{b}-v_{i j}^{o}} & \frac{v_{i p}^{a}+v_{i p}^{b}}{2} \leq v_{i j}^{o} \\ v_{i p}^{b}-u_{i j}^{b} & \frac{v_{i p}^{a}+v_{i p}^{b}}{2} \in\left\langle u_{i j}^{a}, u_{i j}^{b}\right\rangle\end{cases}
$$


Thus, the current extension dependency function $K_{i j}$ of the measurement analysis index i of corporate green technology innovation capacity and the jth measurement analysis scale is:

$$
K_{i j}= \begin{cases}-\rho_{i j}^{p} /\left|u_{i j}^{a}-u_{i j}^{b}\right| & \left\langle v_{i p}^{a}, v_{i p}^{b}\right\rangle \in\left\langle u_{i j}^{a}, u_{i j}^{b}\right\rangle \\ 0 & \rho_{i j}^{o}-\rho_{i j}^{p}=0 \\ \rho_{i j}^{p} /\left(\rho_{i j}^{o}-\rho_{i j}^{p}\right) & \left\langle v_{i p}^{a}, v_{i p}^{b}\right\rangle \notin\left\langle u_{i j}^{a}, u_{i j}^{b}\right\rangle\end{cases}
$$

In the function above, $\rho_{i j}^{o}$ represents the current extension distance between the measurement analysis index $i$ and its corresponding controlled field matter element.

Taking into account that different measurement analysis index might have different weight $w_{i}$, the weighting extension dependency $\Psi_{j}$ between the measurement analysis indexes of corporate technology innovation and the jth measurement analysis scale is:

$$
\Psi_{j}=\sum_{i=1}^{m}\left(w_{i} * K_{i j}\right)
$$

Then according to the size of weighting extension dependency $\Psi_{j}$, the current performance level of corporate green technology innovation can be obtained. The rule of optimal selection is as follows:

$$
\Psi_{o}=\max \left(\Psi_{1}, \Psi_{2}, \cdots, \Psi_{n}\right)=\Psi_{k}
$$

The performance measurement analysis level of corporate green technology innovation

$\mathrm{k}$ which corresponds to ${ }^{\Psi_{k}}$ is the current performance level of corporate green technology innovation. By doing so, a precise quantitative description of the current performance level of corporate green technology innovation is realized. The results can offer support and guidance to the following corporate green sustainable development.

\subsection{Model and Algorithm Implementation}

Taken all information mentioned above into account, there are seven specific steps to implement the performance extension measurement analysis model of corporate green technology innovation and they are as follow:

Step 1: On the basis of the implementing of corporate green technology, establish the performance measurement analysis index system of corporate green technology innovation;

Step 2: With the guidance of the index system above, construct classical field matter elements and controlled field matter elements of different types of measurement analysis indexes;

Step 3: Standardize different types of measurement analysis indexes to generate unified indexes;

Step 4: Collect performance measurement analysis index data of current corporate green technology innovation through research and analysis and then standardize all of them;

Step 5: Calculate the extension distance between the measurement analysis index data of current corporate green technology innovation and the corresponding classical field matter elements and controlled field matter elements;

Step 6: Calculate the extension dependency function and weighting extension dependency between the measurement analysis index data of current corporate green technology innovation and the corresponding classical field matter elements; 
Step 7: Based on the size of the weighting extension dependency, find out the level of current corporate green technology innovation and offer support and guidance to the following corporate green sustainable development

\section{Case Analysis and Testing}

In the following chapter, the performance measurement analysis of a specific company's green technology innovation will be studied to further explain and analyze the model and algorithm introduced in this thesis. By soliciting expert opinions and corporate researches, classical fields in the performance measurement analysis index system of corporate green technology innovation are obtained and relevant indexes are collected. Specific results are demonstrated in Table 2.

Table 2. Performance Measurement Analysis Indexes of Corporate Green Technology Innovation

\begin{tabular}{|c|c|c|c|c|c|c|c|}
\hline \multirow[b]{2}{*}{ Criterion layer } & \multirow[b]{2}{*}{ weight } & \multirow[b]{2}{*}{ index layer } & \multirow[b]{2}{*}{ weight } & \multicolumn{3}{|c|}{ Measurement level } & \multirow{2}{*}{$\begin{array}{l}\text { Measured } \\
\text { value }\end{array}$} \\
\hline & & & & $\begin{array}{c}\text { I } \\
\text { LEVEL }\end{array}$ & $\begin{array}{c}\text { II } \\
\text { LEVEL }\end{array}$ & $\begin{array}{c}\text { III } \\
\text { LEVEL }\end{array}$ & \\
\hline \multirow{4}{*}{$\begin{array}{c}\text { green } \\
\text { innovation } \\
\text { research and } \\
\text { development } \\
\text { capacity } A_{1}\end{array}$} & \multirow{4}{*}{0.20} & $\begin{array}{l}\text { number of } \\
\text { patents } \\
\text { owned } a_{11}\end{array}$ & 0.15 & $0-10$ & $10-20$ & $20-40$ & 16 \\
\hline & & $\begin{array}{l}\text { innovation } \\
\text { development } \\
\text { cycle } a_{12}\end{array}$ & 0.30 & $1.0-2.0$ & $0.5-1.0$ & $0-0.5$ & $0.4-0.6$ \\
\hline & & $\begin{array}{c}\text { Independent } \\
\text { research and } \\
\text { development } \\
\text { rate } a_{13} \\
\end{array}$ & 0.30 & $0-0.2$ & $0.2-0.5$ & $0.5-1.0$ & 0.6 \\
\hline & & $\begin{array}{l}\text { Training and } \\
\text { learning } \\
\text { ability } a_{14}\end{array}$ & 0.25 & $0-0.4$ & $0.4-0.7$ & $0.7-1.0$ & 0.8 \\
\hline \multirow{3}{*}{$\begin{array}{c}\text { green } \\
\text { innovation } \\
\text { implementation } \\
\text { capacity } A_{2}\end{array}$} & \multirow{3}{*}{0.20} & $\begin{array}{l}\text { level of green } \\
\text { equipment } a_{21}\end{array}$ & 0.35 & $0-0.4$ & $0.4-0.7$ & $0.7-1.0$ & 0.6 \\
\hline & & $\begin{array}{l}\text { level of green } \\
\text { technology } a_{22}\end{array}$ & 0.35 & $0-0.4$ & $0.4-0.7$ & $0.7-1.0$ & $0.65-0.75$ \\
\hline & & $\begin{array}{c}\text { proportion of } \\
\text { professional } \\
\text { green technology } \\
\text { personnel } a_{23}\end{array}$ & 0.30 & $0-0.2$ & $0.2-0.4$ & $0.4-1.0$ & 0.3 \\
\hline \multirow{3}{*}{$\begin{array}{c}\text { green } \\
\text { innovation } \\
\text { management } \\
\text { capacity } A_{3}\end{array}$} & \multirow{3}{*}{0.12} & $\begin{array}{l}\text { Entrepreneur's } \\
\text { green innovation } \\
\text { consciousness } a_{31}\end{array}$ & 0.20 & $0-0.4$ & $0.4-0.7$ & $0.7-1.0$ & 0.8 \\
\hline & & $\begin{array}{c}\text { Rationality of } \\
\text { innovation } \\
\text { mechanism } a_{32}\end{array}$ & 0.30 & $0-0.4$ & $0.4-0.7$ & $0.7-1.0$ & $0.7-0.8$ \\
\hline & & $\begin{array}{l}\text { Rationality of } \\
\text { innovation } \\
\text { mechanism } a_{33}\end{array}$ & 0.20 & $0-0.5$ & $0.5-0.8$ & $0.8-1.0$ & $0.8-0.9$ \\
\hline
\end{tabular}




\begin{tabular}{|c|c|c|c|c|c|c|c|}
\hline & & $\begin{array}{l}\text { Rationality of } \\
\text { organizational } \\
\text { structure } a_{34}\end{array}$ & 0.30 & $0-0.5$ & $0.5-0.8$ & $0.8-1.0$ & $0.75-0.85$ \\
\hline \multirow{3}{*}{$\begin{array}{c}\text { green } \\
\text { innovation } \\
\text { marketing } \\
\text { capacity } A_{4}\end{array}$} & \multirow{3}{*}{0.15} & market share $a_{41}$ & 0.40 & $0-0.2$ & $0.2-0.4$ & $0.4-1.0$ & 0.15 \\
\hline & & $\begin{array}{c}\text { capacity of } \\
\text { maintaining } \\
\text { market share } a_{42}\end{array}$ & 0.30 & $0-0.5$ & $0.5-0.8$ & $0.8-1.0$ & 0.4 \\
\hline & & $\begin{array}{c}\text { Return on } \\
\text { marketing } a_{43}\end{array}$ & 0.30 & $0-0.2$ & $0.2-0.4$ & $0.4-1.0$ & 0.3 \\
\hline \multirow{3}{*}{$\begin{array}{l}\text { green } \\
\text { innovation } \\
\text { input } \\
\text { capacity } A_{5}\end{array}$} & \multirow{3}{*}{0.18} & $\begin{array}{c}\text { input-output ratio } \\
a_{51}\end{array}$ & 0.30 & $0-0.2$ & $0.2-0.5$ & $0.5-1.0$ & 0.4 \\
\hline & & $\begin{array}{c}\text { Conversion rate } \\
\text { of scientific and } \\
\text { technical } \\
\text { achievements } a_{52}\end{array}$ & 0.40 & $0-0.2$ & $0.2-0.5$ & $0.5-1.0$ & 0.6 \\
\hline & & invested cost $a_{53}$ & 0.30 & $0-100$ & $\begin{array}{l}100- \\
300\end{array}$ & $\begin{array}{c}300- \\
500\end{array}$ & 400 \\
\hline \multirow{3}{*}{$\begin{array}{c}\text { green } \\
\text { innovation } \\
\text { development } \\
\text { potential } A_{6}\end{array}$} & \multirow{3}{*}{0.15} & $\begin{array}{c}\text { Intensity of green } \\
\text { innovation } \\
\text { input } a_{61}\end{array}$ & 0.30 & $0-0.5$ & $0.5-0.8$ & $0.8-1.0$ & 0.95 \\
\hline & & $\begin{array}{c}\text { High-tech } \\
\text { projects of green } \\
\text { cooperation } a_{62}\end{array}$ & 0.30 & $0-2$ & $2-5$ & $5-10$ & 4 \\
\hline & & $\begin{array}{l}\text { Conversion cycle } \\
\text { of green } \\
\text { technology } a_{63}\end{array}$ & 0.40 & $2-4$ & $1-2$ & $0-1$ & 0.8 \\
\hline
\end{tabular}

Based on the extension distance calculation model introduced in the thesis, the extension distances between the performance measurement analysis indexes of the current corporate green technology innovation and related classical fields and controlled fields are obtained. The specific results are shown in Table 3.

Table 3. The Extension Distances of Performance Measurement Analysis of the Current Corporate Green Technology Innovation

\begin{tabular}{|c|c|c|c|}
\hline \multirow{2}{*}{ index layer } & \multicolumn{3}{|c|}{ Extension distance } \\
\cline { 2 - 4 } & I LEVEL & II LEVEL & III LEVEL \\
\hline number of patents owned $a_{11}$ & 0.15 & -0.1 & 0.1 \\
\hline innovation development cycle $a_{12}$ & 0 & 0.25 & 0.25 \\
\hline $\begin{array}{c}\text { Independent research and } \\
\text { development rate } a_{13}\end{array}$ & 0.4 & 0.1 & -0.1 \\
\hline Training and learning ability $a_{14}$ & 0.4 & 0.1 & -0.1 \\
\hline level of green equipment $a_{21}$ & 0.2 & -0.1 & 0.1 \\
\hline level of green technology $a_{22}$ & 0.3 & 0 & 0 \\
\hline $\begin{array}{c}\text { proportion of professional green } \\
\text { technology personnel } a_{23}\end{array}$ & 0.1 & -0.1 & 0.1 \\
\hline
\end{tabular}




\begin{tabular}{|c|c|c|c|}
\hline $\begin{array}{l}\text { Entrepreneur's green innovation } \\
\text { consciousness } a_{31}\end{array}$ & 0.4 & 0.1 & -0.1 \\
\hline $\begin{array}{l}\text { Rationality of innovation } \\
\text { mechanism } a_{32}\end{array}$ & 0.35 & 0.05 & -0.05 \\
\hline $\begin{array}{l}\text { Rationality of innovation } \\
\text { mechanism } a_{33}\end{array}$ & 0.35 & 0.05 & -0.05 \\
\hline $\begin{array}{l}\text { Rationality of organizational } \\
\text { structure } a_{34}\end{array}$ & 0.30 & 0 & 0 \\
\hline market share $a_{41}$ & -0.05 & 0.05 & 0.25 \\
\hline $\begin{array}{l}\text { capacity of maintaining market } \\
\text { share } a_{42}\end{array}$ & -0.1 & 0.1 & 0.4 \\
\hline Return on marketing $a_{43}$ & 0.1 & -0.1 & 0.1 \\
\hline input-output ratio $a_{51}$ & 0.2 & -0.1 & 0.1 \\
\hline $\begin{array}{c}\text { Conversion rate of scientific and } \\
\text { technical achivements } a_{52}\end{array}$ & 0.4 & 0.1 & -0.1 \\
\hline invested cost $a_{53}$ & 0.6 & 0.2 & -0.2 \\
\hline $\begin{array}{l}\text { Intensity of green innovation } \\
\text { input } a_{61}\end{array}$ & 0.45 & 0.15 & -0.05 \\
\hline $\begin{array}{l}\text { High-tech projects of green } \\
\text { cooperation } a_{62}\end{array}$ & 0.2 & -0.1 & 0.1 \\
\hline $\begin{array}{l}\text { Conversion cycle of green } \\
\text { technology } a_{63}\end{array}$ & 0.3 & 0.05 & -0.05 \\
\hline
\end{tabular}

On the basis of the extension dependency function calculation model introduced in the thesis, the extension dependency functions of the performance measurement analysis indexes of the current corporate green technology innovation and related classical fields are obtained. The specific results are shown in Table 4.

Table 4. The Extension Dependency Functions of the Performance Measurement Analysis Indexes of the Current Corporate Green Technology Innovation

\begin{tabular}{|c|c|c|c|}
\hline \multirow{2}{*}{ index layer } & \multicolumn{3}{|c|}{ Extension dependency functions } \\
\cline { 2 - 4 } & I LEVEL & II LEVEL & III LEVEL \\
\hline $\begin{array}{c}\text { number of patents } \\
\text { owned } a_{11}\end{array}$ & -0.231 & 0.4 & -0.200 \\
\hline $\begin{array}{c}\text { innovation development } \\
\text { cycle } a_{12}\end{array}$ & 0 & -0.333 & -0.333 \\
\hline $\begin{array}{c}\text { Independent research and } \\
\text { development rate } a_{13}\end{array}$ & -0.500 & -0.200 & 0.200 \\
\hline $\begin{array}{c}\text { Training and learning } \\
\text { ability } a_{14}\end{array}$ & -0.667 & -0.333 & 0.333 \\
\hline $\begin{array}{c}\text { level of green } \\
\text { equipment } a_{21}\end{array}$ & -0.333 & 0.333 & -0.200 \\
\hline
\end{tabular}




\begin{tabular}{|c|c|c|c|}
\hline $\begin{array}{l}\text { level of green } \\
\text { technology } a_{22}\end{array}$ & -0.500 & 0 & 0 \\
\hline $\begin{array}{l}\text { proportion of professional } \\
\text { green technology } \\
\text { personnel } a_{23}\end{array}$ & -0.250 & 0.500 & -0.250 \\
\hline $\begin{array}{l}\text { Entrepreneur's green } \\
\text { innovation } \\
\text { consciousness } a_{31}\end{array}$ & -0.667 & -0.333 & 0.333 \\
\hline $\begin{array}{l}\text { Rationality of innovation } \\
\text { mechanism } a_{32}\end{array}$ & -0.583 & -0.083 & 0.167 \\
\hline $\begin{array}{l}\text { Rationality of innovation } \\
\text { mechanism } a_{33}\end{array}$ & -0.700 & -0.100 & 0.25 \\
\hline $\begin{array}{c}\text { Rationality of } \\
\text { organizational } \\
\text { structure } a_{34}\end{array}$ & -0.600 & 0 & 0 \\
\hline market share $a_{41}$ & 0.250 & -0.250 & -0.625 \\
\hline $\begin{array}{l}\text { capacity of maintaining } \\
\text { market share } a_{42}\end{array}$ & 0.200 & -0.200 & -0.500 \\
\hline Return on marketing $a_{43}$ & -0.250 & 0.250 & -0.250 \\
\hline input-output ratio $a_{51}$ & -0.333 & 0.333 & -0.200 \\
\hline $\begin{array}{c}\text { Conversion rate of } \\
\text { scientific and technical } \\
\text { achivements } a_{52}\end{array}$ & -0.500 & -0.200 & 0.200 \\
\hline invested cost $a_{53}$ & -0.750 & -0.500 & 0.500 \\
\hline $\begin{array}{l}\text { Intensity of green } \\
\text { innovation input } a_{61}\end{array}$ & -0.900 & -0.750 & 0.25 \\
\hline $\begin{array}{l}\text { High-tech projects of } \\
\text { green cooperation } a_{62}\end{array}$ & -0.333 & 0.333 & -0.250 \\
\hline $\begin{array}{l}\text { Conversion cycle of green } \\
\text { technology } a_{63}\end{array}$ & -0.600 & -0.200 & 0.200 \\
\hline
\end{tabular}

Based on the extension dependency calculation model introduced in the thesis, the sequence of the extension dependency of the performance measurement analysis indexes of the current corporate green technology innovation is obtained:

$\Psi_{o}=(-0.412,-0.067,-0.019)$. From this sequence it can be seen that the current ability level of the corporate green technology innovation is $\Psi_{\text {III }}$, however, the difference between $\Psi_{\text {III }}$ and $\Psi_{\text {II }}$ is not obvious. Thus, targeted improvements to deal with the weak links are necessary so that the model is able to offer support and guidance for corporate green sustainable development in the future.

\section{Conclusions}

This paper, to deal with the existing problems of corporate green technology innovation, has proposed a performance extension measurement analysis model of 
corporate green technology innovation. This model standardizes different types of measurement analysis indexes via the establishment of a performance measurement analysis index system of corporate green technology innovation. Then it constructs corresponding classical field matter elements and the controlled field matter elements of relevant indexes after which the extension distances and extension dependencies of the corporate green technology innovation capacities and the classical field matter elements are calculated by the extension distance and dependency calculation model. The size of the extension dependency shows the capacity level of corporate green technology innovation. The model demonstrates well-defined physical significance and its calculation is simple, accurate and can easily be applied to computers. As a result, it can provide a new way of intelligent implementation for the measurement of corporate green technology innovation. Meanwhile, the testing results of the practical cases have proven that the proposed model and algorithm are effective.

\section{References}

[1] W. Xu, Q. Shusheng and W. Kuan, "The Exploration of Corporate Green Technology Innovation Drive Green Development”, Technoeconomics \& Management Research, no. 8, (2014), pp. 26-29.

[2] C. Limeng, "Status Quo of green technology innovation research in China", Contemporary Economics, no. 1, (2014), pp. 153-155.

[3] G. Xiaomei, W. Jinfang and X. Bin, "Solutions to promote green technology innovation in SME", Science of Science and Management of S. T, no. 12, (2005), pp. 87-91.

[4] S. Shude, "Review of Research on Technology Innovation Capability Assessment of Firm", Science and Technology Management Research, no. 10, (2013), pp. 13-16+21.

[5] Z. Hua, "Evaluation of corporate technology innovation capacity based on improved DEA model", Chinese Journal of Systems Science, no. 4, (2010), pp. 86- 90.

[6] Z. Ying and D. Weiping, "Evaluation index system of green technology innovation diffusion", Productivity Research, no. 20, (2007), pp. 67-68.

[7] Z. Yongyue, M. Zhiqiang and C. Yongqing, "Multilevel comprehensive evaluation of corporate green technology innovation environment", Science \& Technology Progress And Policy, vol. 27, no. 9, (2010), pp. 102-105.

[8] Y. Qian, "Application of fuzzy comprehensive evaluation method in evaluation of technology innovation projects", Project Management Technology, vol. 11, no. 5, (2013), pp. 87-90.

[9] W. Fan and L. Jin, "Evaluation system of Corporate technology innovation capacity based on customer knowledge", Science \& Technology Progress and Policy, vol. 30, no. 10, (2013), pp. 131-135.

[10] W. Ti-Chun, Y. Ai-Jun and B. U. Liang-feng, "Mechanism scheme design based on multi-attribute extension gray relevant optimized decision-making model", Systems Engineering-Theory \& Practice, vol. 33, no. 9, (2013), pp. 2321-2329.

[11] H. Tu, J. Zhihong and Z. Qiulin, "Heterogeneous network selection algorithm based onextension theory and fuzzy analytic hierarchy process", Journal of Computer Applications, vol. 31, no. 9, (2011), pp. 2236-2239.

[12] R. Yundan and R. Yannian, "An Overall Evaluation Method for Mold Design Schemes of Complex Cavity Based on the Extension Methodology", Mechanical Science and Technology for Aerospace Engineering, vol. 32, no. 4, (2013), pp. 620-624.

[13] T.-C. Wang, A.-J. Yang and S.-S. Zhong, "Multi-Attribute Extension Fuzzy Optimized DecisionMaking Model Of Scheme Design”, Tehnički vjesnik/Technical Gazette, vol. 21, no. 2, (2014), pp. 239247.

[14] C. Wen and Y. Chunyan, "Basic theories and method system of extenics", Chinese Science Bulletin, vol. 58, no. 13, (2013), pp. 1190-1199.

[15] Z. Hongsheng and W. Zhengying, "Product design based Multi-attribute extension decision-making model and its application", Journal of Chinese Computer Systems, vol. 35, no. 5, (2014), pp. 1147-1150. 
International Journal of Hybrid Information Technology Vol.8, No.11 (2015) 